\title{
COVID-19 Pandemic: Development of Digital Technologies that Provide Connection, Collaboration and Lifelong Learning
}

INNA H. OTAMAS ${ }^{1}$, VIKTORIIA O. ANISHCHENKO ${ }^{2}$, LIUDMYLA A. OVSIANKINA ${ }^{3}$, INNA A. AFANASIEVA ${ }^{4}$, ANDRII BIELIATYNSKYI ${ }^{5}$

${ }^{1}$ Department of Professional and Higher Education, Central Institute of Postgraduate Education, State Institution of Higher Education UNIVERSITY OF EDUCATIONAL MANAGEMENT, UKRAINE

${ }^{2}$ Department of Pedagogy and Humanitarian Sciences, ACADEMY OF THE STATE PENITENTIARY SERVICE, UKRAINE

${ }^{3}$ Department of Philosophy, Faculty of History and Philosophy, BORYS GRINCHENKO KYIV UNIVERSITY, UKRAINE ${ }^{4}$ Department of Clinical Pharmacology and Clinical Pharmacy, BOGOMOLETS NATIONAL MEDICAL UNIVERSITY, UKRAINE

${ }^{5}$ School of Civil Engineering, NORTH MINZU UNIVERSITY, P.R. CHINA. E-mail: beljatynskij@ukr.net

\begin{abstract}
The purpose of the article is to reveal the essence of initiatives of international organizations during the impact of COVID-19 on educational institutions in the world and in Ukraine, to identify and analyze the quality of education and ensure constant updating of educational content based on the latest advances in culture, science and technology, use of information technologies in the educational process during COVID-19. The value of this article is to provide a holistic picture of current online teaching and learning activities, including the link between change management and the online teaching and learning process in the education system after the COVID-19 outbreak.
\end{abstract}

Keywords: Educational system in the conditions of COVID-19; Innovative technologies in the educational process; Digital communication; Distance education; Online learning platforms.

JEL Classification: I15, Q55. 


\title{
Pandemia de COVID-19: Desarrollo de Tecnologías Digitales que Brindan Conexión, Colaboración y Aprendizaje Permanente
}

\author{
INNA H. OTAMAS ${ }^{1}$, VIKTORIIA O. ANISHCHENKO ${ }^{2}$, LIUDMYLA A. OVSIANKINA ${ }^{3}$, \\ INNA A. AFANASIEVA ${ }^{4}$, ANDRII BIELIATYNSKYI ${ }^{5}$ \\ ${ }^{1}$ Department of Professional and Higher Education, Central Institute of Postgraduate Education, State \\ Institution of Higher Education UNIVERSITY OF EDUCATIONAL MANAGEMENT, UKRAINE \\ ${ }^{2}$ Department of Pedagogy and Humanitarian Sciences, ACADEMY OF THE STATE PENITENTIARY SERVICE, \\ UKRAINE \\ ${ }^{3}$ Department of Philosophy, Faculty of History and Philosophy, BORYS GRINCHENKO KYIV UNIVERSITY, UKRAINE \\ ${ }^{4}$ Department of Clinical Pharmacology and Clinical Pharmacy, BOGOMOLETS NATIONAL MEDICAL UNIVERSITY, \\ UKRAINE \\ ${ }^{5}$ School of Civil Engineering, NORTH MINZU UNIVERSITY, P.R. CHINA. E-mail: beljatynskij@ukr.net
}

\begin{abstract}
RESUMEN
El propósito del artículo es revelar la esencia de las iniciativas de las organizaciones internacionales durante el impacto del COVID-19 en las instituciones educativas en el mundo y en Ucrania, para identificar y analizar la calidad de la educación y asegurar la actualización constante de los contenidos educativos basados en la últimos avances en cultura, ciencia y tecnología, uso de tecnologías de la información en el proceso educativo durante COVID-19. El valor de este artículo es proporcionar una imagen holística de las actividades actuales de enseñanza y aprendizaje en línea, incluido el vínculo entre la gestión del cambio y el proceso de enseñanza y aprendizaje en línea en el sistema educativo después del brote de COVID-19.
\end{abstract}

Palabras clave: Sistema educativo en las condiciones de COVID-19; Tecnologías innovadoras en el proceso educativo; Comunicación digital; Educación a distancia; Plataformas de aprendizaje en línea.

Clasificación JEL: I15, Q55. 


\section{Introduction}

Seeing that the world is becoming more interconnected, various risks are growing, beyond that COVID-19 pandemic do not stop at national borders. It has affected people, regardless of nationality, level of education, gender or wealth. The pandemic had a particularly significant impact on the most vulnerable segments of the population, in particular, socially disadvantaged families and students. Privileged students, as well as those willing to study, those who are supported by their parents, could receive alternative education during the pandemic, when educational institutions are closed. The crisis has exposed many challenges in education systems, from access to broadband and computers needed for online learning, to support environments needed to focus learning, to the mismatch between resources and needs (The impact of COVID-19..., 2020).

Young people face the inability to obtain education and employment, as well as high unemployment due to the COVID-19 pandemic. Instead, investing in youth can provide a reliable way to recover from COVID-19. Job creation programs, trainings for young people should respond to the consequences and systemic long-term challenges faced by young people (Borysenko et al., 2020; Kozlovskyi et al., 2019). The COVID-19 pandemic has contributed to some injustice in our global economic and social systems. This has made it clear that the crisis has affected not only some of the most vulnerable and undervalued professions in our society, but also those we have relied on the most.

In addition to the COVID-19 pandemic, we face one of the greatest challenges of the 21st century: the mismatch between the qualifications of domestic young professionals and the level of qualifications of the world economy. Verification of competencies and competencies will be important, as we see the constant rapid development of all sectors of the world economy. According to the latest report of the World Economic Forum "Tasks of Tomorrow", the demand for digital and human factors will grow. It is important to provide youth and society with lifelong learning, especially during challenges such as the pandemic (COVID-19: Why investing in youth..., 2020).

From its part, the International Partnership of Distance and Online Learning for COVID-19 (2020) noted that the unprecedented events caused by COVID-19 have led to the closure of educational institutions around the world. UNESCO estimates that more than $90 \%$ of the world's student population cannot attend classes and must stay at home. Students studying in countries that do not have access to appropriate devices and Internet connections are particularly vulnerable (Anishchenko et al., 2010; Yaroshenko et al., 2018).

The rapid spread of 'digital' technologies makes digital skills (competencies) key among other skills. Thus, "digitalization" and cross-platform are now the main trends in the general labor market. Thus, the ability to work with "digital" technologies is gradually becoming permanent and necessary for most specializations, namely end-to-end or cross-platform. The uniqueness of digital competencies lies in the fact that thanks to them citizens can more effectively acquire competencies in many other areas (for example, learning languages, subjects, professions, etc.) (Al-Samarrai et al., 2020).

\section{Methodological Framework}

During 2020, articles and reports of the International Association of Universities were published with a global survey to inform the public about the impact of COVID-19 on educational institutions (EI). Joint documents of the International Association of Universities (IAU) (2020) set out the essence of their research on the impact of COVID-19 on educational institutions (Join paper..., 2020). The brochures, published under the responsibility of A. Schleicher, Secretary-General of the Organization for Economic Co-operation and Development (OECD), on the global spread of COVID-19 and its impact on higher education, highlight indicators from "Education at a Glance" (OECD, 2020a), their analysis, which allows us to understand the reaction of countries and the potential impact of the pandemic on education.

Distance learning is a measure that helps to transfer the traditional teaching process in the classroom online. The latest technological developments and expanded access to mobile applications 
open up new opportunities, but they need to be adapted to specific conditions. Therefore, the Commonwealth of Learning (COL) has issued "Recommendations on Distance Education during COVID$19 "$, which contain practical advice on the use of methods, tools for distance learning and related technologies. The publication was issued as a measure at COL for the COVID-19 crisis to help those interested in making effective use of distance learning (COL, 2020).

A. Schleicher made a significant contribution to the study of the use of open education technologies, noting that distance learning offers a certain integrity in learning when it comes to academic training, vocational education (VE). Compared to general programs, VE programs suffer from distancing and business closures. However, this sector plays an important role in ensuring coordination between education and work, the successful transition of students to the labor market. Yes, many professions that formed the backbone of economic and social life during a pandemic depend on professional qualifications. Therefore, learning flows should not be the first victims in education. Organization for Economic Cooperation and Development (OECD) take measures to support and prolongate greater use of online and virtual platforms in VE institutions to ensure continuity of learning (OECD, 2020b)

\section{Results}

Like many other industries, the education sector has been severely affected by the COVID-19 pandemic. Fortunately, there are many free (or inexpensive) easy-to-use digital means of communication that provide ample opportunities to address distance learning. Teachers, students and families are still struggling with the immediate task of conducting online classes and distance learning in their homes. International organizations pay considerable attention to distance learning and the use of modern innovative technologies in education, work and life.

Today it is one of the important components in the socio-economic protection of the population. UNESCO offers a comprehensive list of distance learning solutions, including educational programs, platforms and resources designed to help parents, teachers, schools and school administrators facilitate student learning and provide social assistance and interaction during school closures. Most curatorial decisions are free, and many cater to different languages. Although these decisions do not have explicit UNESCO approval, they tend to have a broad coverage, a strong user base and evidence of impact. They are classified according to distance learning needs, but most of them offer functionality for different categories (table 1) (Distance learning solutions, 2020).

Commonwealth of Learning (Commonwealth of Learning - COL), is the only intergovernmental organization in the world that has been exclusively involved in the introduction and development of distance education since 1987. This organization was created to promote the development and exchange of knowledge, resources and technologies of open learning and distance education. In these difficult times. In their research, they noted the benefits of distance education, namely: can increase access to education, improve quality, reduce costs, can expand access to education for a large number of students. Commonwealth universities alone serve more than 4.4 million students, while the National Open School Institute (India) reports a total enrollment of 2.71 million. Because of its flexibility, it is beneficial to students who have family or social responsibilities.

Distance education provides an opportunity for people with inclusion to learn. Mixed approaches are introduced in technical and vocational education for training. Research shows that there is no "significant difference" between distance and traditional learning in the classroom in terms of learning outcomes, if everything is designed well. Moreover, distance learning is based on student-centered education, promoting lifelong skills such as self-directed learning, discipline and critical thinking. Recent rapid research from Australia suggests that blended learning, combining face-to-face and distance learning, may be as effective as classroom learning for many students (COL, 2020). 
Table 1. The list of educational programs, platforms and resources (UNESCO)

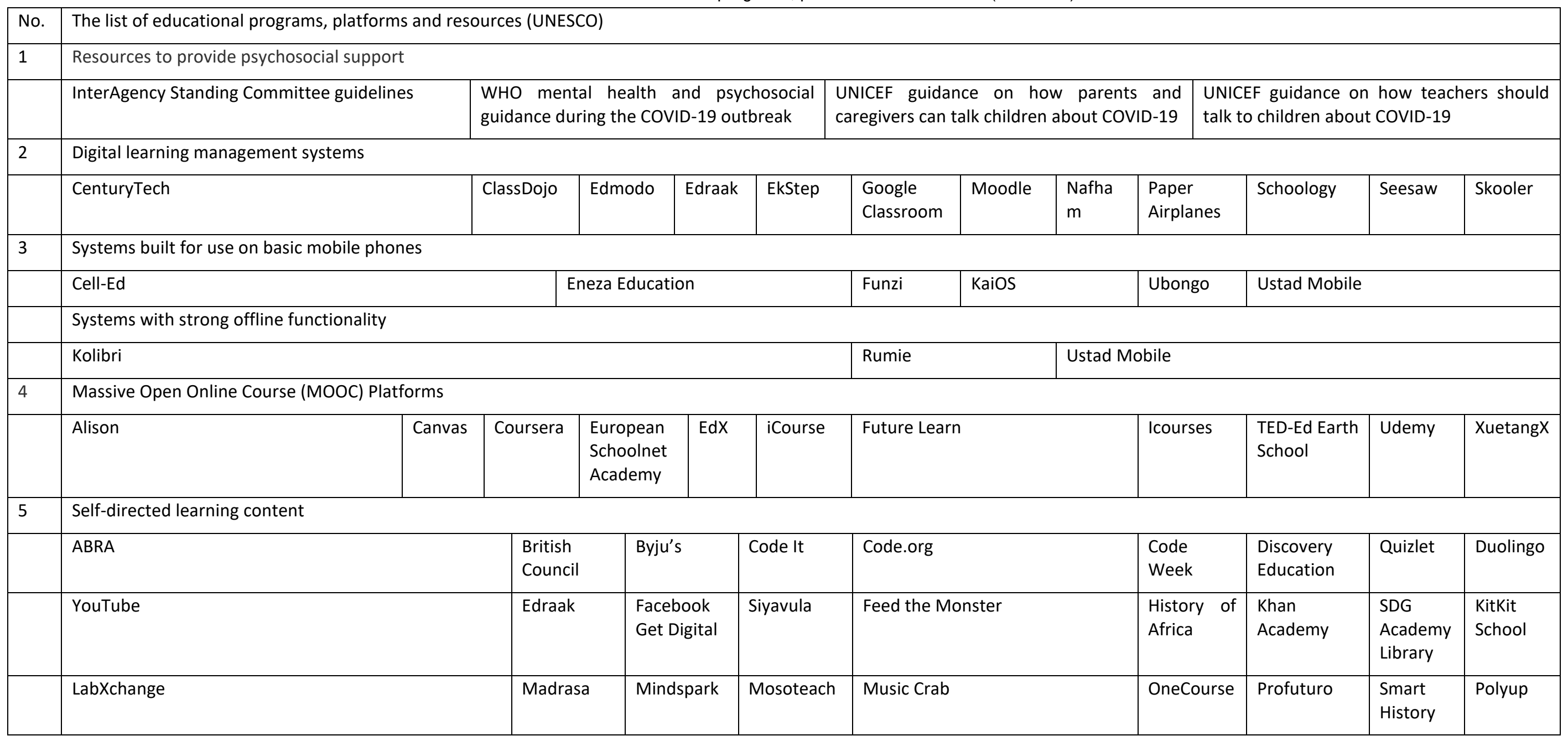


Figure 1. Learning Resources (COL)

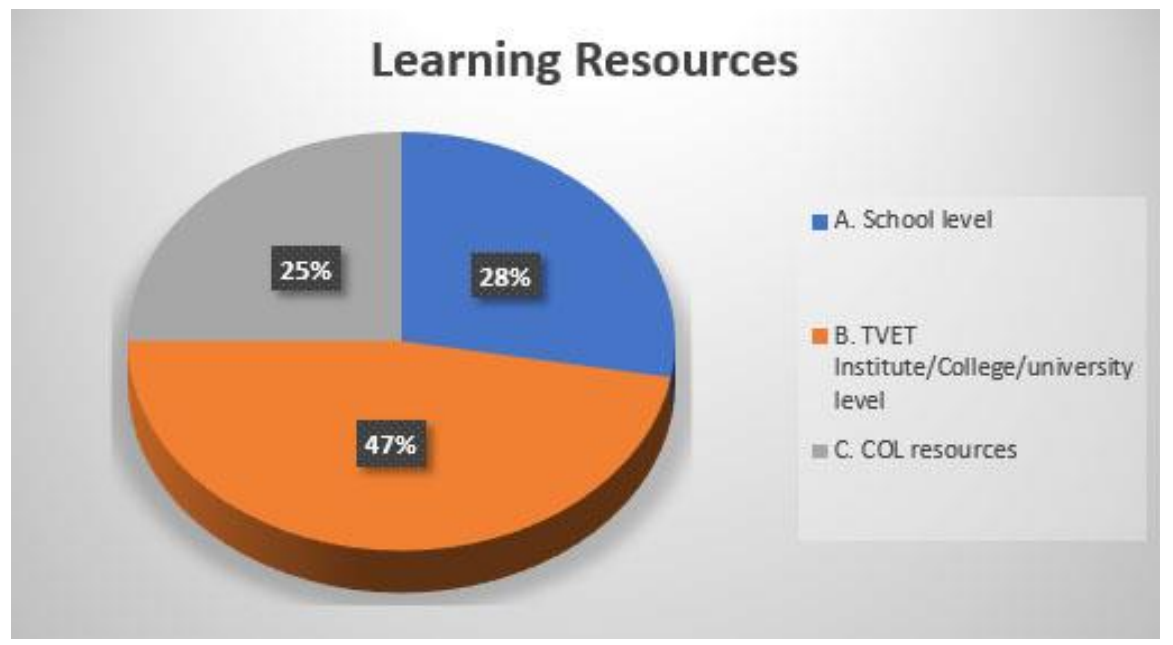

During a pandemic, Open and Distance Learning (ODL) can support learning in the non-formal and formal education sectors. The following is a curatorial list of resources for politicians, school administrators, colleges, teachers, parents, and students posted on the COL website to help students to close educational institutions. In fig. 1. educational resources are specified in percent: A. School level; B. TVET Institute / College / University; C. COL Resources (Keeping the doors of learning open COVID-19, 2020).

In fig. 2 lists COL resources for online learning are specified: A. Brief notes and guides for politicians; B. Basic tutorials on online learning, blended learning, open textbooks; C. OER and MOOC; D. Quality assurance; E. Technologies and tools; Links and resources from other organizations (Keeping the doors of learning open COVID -19, 2020).

Figure 2. COL resources on online learning

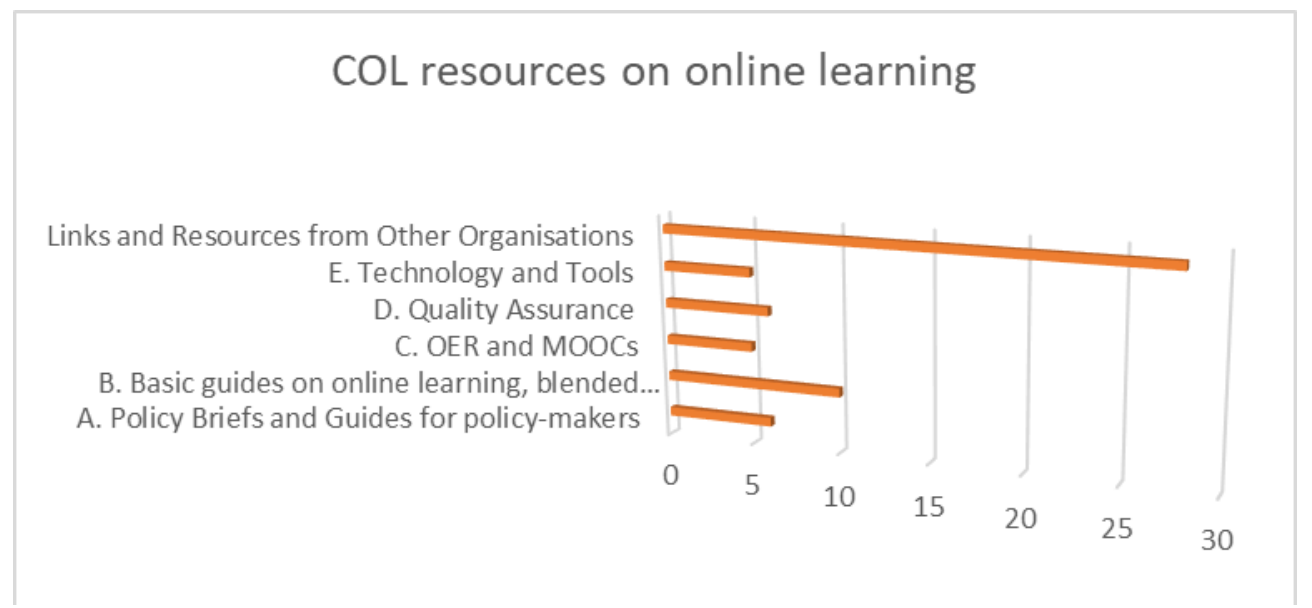

The Organization for Economic Cooperation and Development (OECD) is an international organization working to create better policies for a better life. Most contingency plans include: training during a pandemic (e.g. FRA, ITA); training of teachers and school principals for distance work (e.g. $\mathrm{CHN}, \mathrm{GBR}$ ), creation of online classes (for example CHN).

Like many other industries, the education sector has been severely affected by the COVID-19 pandemic. During a pandemic, there are free (or inexpensive) easy-to-use digital communications tools that provide a wide range of distance learning solutions. At present, teachers, students and families are still struggling with the immediate task of conducting online classes and distance learning in the company of their relatives. 
UNESCO offers a comprehensive list of distance learning solutions, including educational programs, platforms and resources, to help parents, teachers, schools and school administrators facilitate student learning and provide social assistance and interaction during school closures (COVID-19: How digital learning solutions..., 2020). To address digital learning on the UNESCO website, there is a list of national learning platforms and tools (National learning platforms and tools, 2020). For example, in Algeria, the National Bureau of Distance Education and Training (Office national d'éducation et de forma à distance), Ministry of Education provides online learning platform on various subjects for all academic levels. For example, the Spanish Educlan is an Internet channel supported by the Ministry of Education that provides educational resources when coronavirus is suspended. Lebanese Ministry of Education application in Arabic, English and French, which can be used by up to six family members. In France, Ma classe à la maison (my lesson at home) is designed so that students can continue their education at home and keep in touch with their teachers. The joint website of the Swiss Eduport State Secretariat for Education, Research and Innovation and the Swiss Conference of Cantonal Ministers of Education contains information, links and resources to support distance learning.

Ministries of Education are expanding measures to ensure lifelong learning. For all countries, avoiding disruptions to children's learning as much as possible is a priority, and they are introducing or expanding existing distance learning methods based on different combinations of technologies. For example, Costa Rica uses social media to communicate daily reading plans to students and parents and encourages students to develop campaigns to curb the spread of the pandemic. Italian Education Minister Lucia Azzolina said: "We use social networking tools to maintain the relationship between teachers and students and keep them motivated." The Estonian Ministry of Education and Research said it was "humiliated" to share all its digital education tools to support other countries' education systems during the COVID-19 crisis. The United Arab Emirates announced a two-week distance learning initiative on March 22 that included all of its students (Fig. 3). (National learning platforms and tools, 2021).

Figure 3. National learning platforms and tools

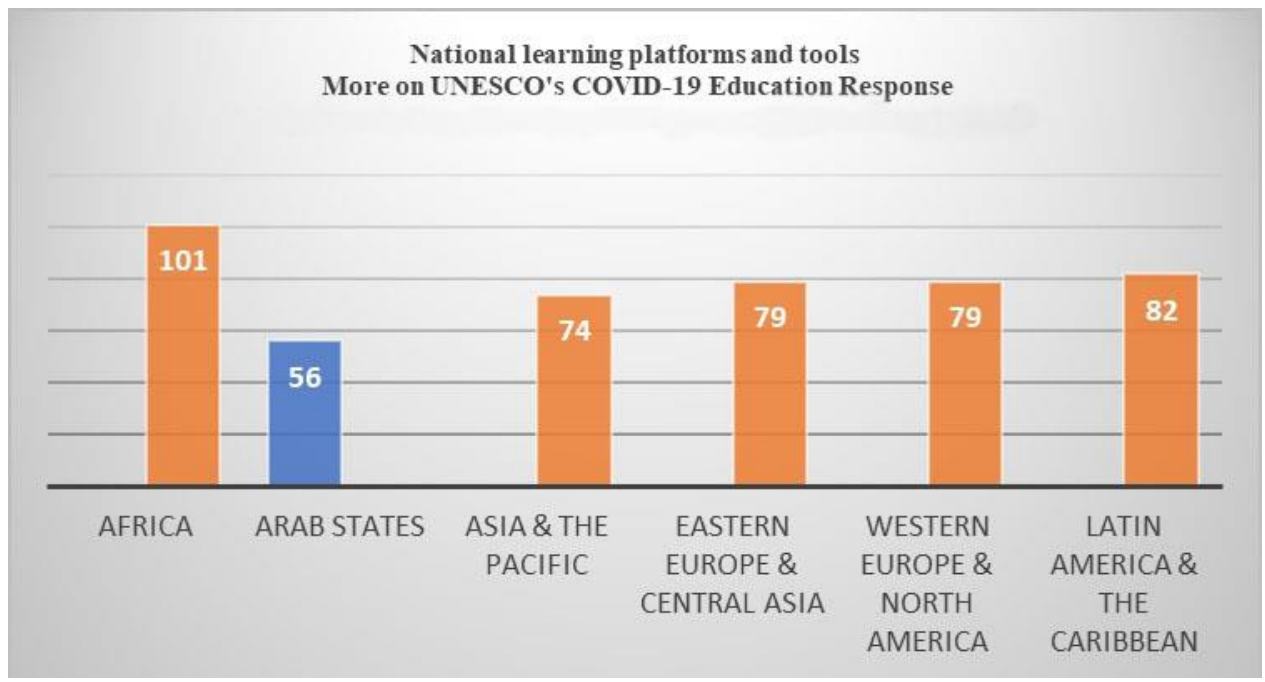

In almost all countries, teachers and school administrators are encouraged to use applications to support communication with students and parents, as well as to conduct real-time lessons or record mass open online courses (MOOC). Learning content is also broadcast on television and other media.

For example, the Spanish Ministry of Education and FP and RTVE launched "Aprendemos en Casa (we study at home)" on March 23 to teach 6-16-years-old to suspend traditional classes. Programs include five hours per day of study. "Only $60 \%$ of students have the Internet, so we had to combine distance education with open television to reach everyone," said Mexican Education Minister Esteban Moktesuma Barragan, adding that his country is also exploring strategies to reach children with special needs. Education and technology join forces. 
China is an example of a pandemic merging the Ministry of Education and the Ministry of Technology to ensure the continuing education of Chinese students when classes were interrupted by a coronavirus outbreak. "China's education system's response to the COVID-19 emergency is extraordinary in terms of the depth of availability of distance learning facilities and the scale needed to meet the needs," said Marielza Oliveira, director of UNESCO's Beijing office. In 2019, the UK Department of Education published a strategy to help education providers and the technology industry. The comprehensive publication includes sections on the development of digital capabilities and skills, promoting digital security (COVID-19: How digital learning solutions..., 2020). To address digital learning in Eastern Europe and Central Asia, the UNESCO website lists national learning platforms and tools (Fig. 4).

Minister of Education Dan Tehan said, that reforms in education in Australia stimulate students and universities meet the needs of the industry, to meet the requirements to qualification for the new economy, which will in result of the pandemic (Australian Government, 2020). During COVID-19, China was the first to suffer from the virus crown, already quite advanced in providing a large proportion of their students access to opportunities for the online training. Partnership with private educational platforms. The complexity of existing resources is the fact that their mass use is not always possible at the same time. Some private sector platforms have already provided their resources and services free access to some schools to enhance countries' response capabilities (e.g., CHN, JPN) (Education responses to COVID-19..., 2020).

Figure 4. Indicators of Eastern Europe and Central Asia on national learning platforms and tools

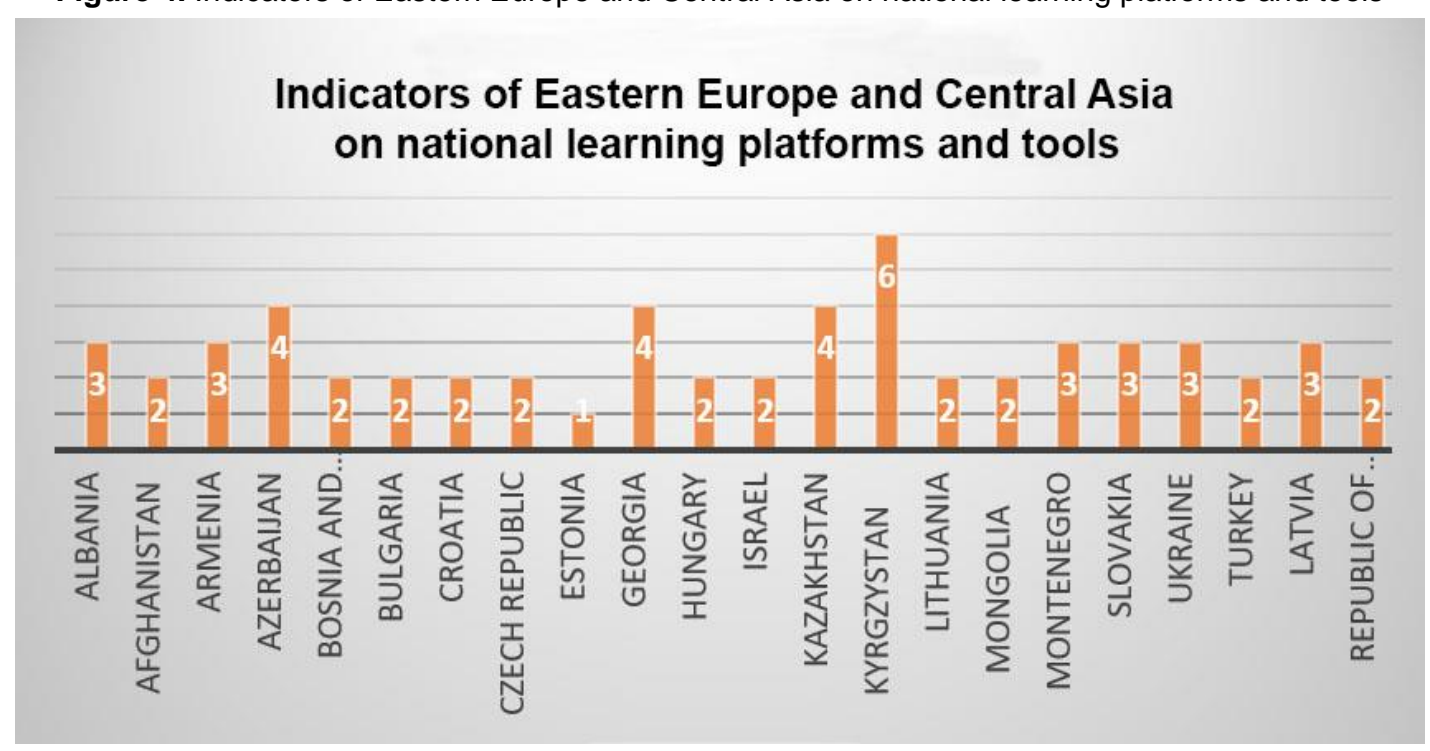

Blandin Ledoux and Coffey Seniahbeto also noted, that the crisis will give lessons which can be used as opportunities. This could turn the provision of educational services in many countries, especially into distance learning. Countries, which will use this benefit, will prepare well for the future of education in the XXI century (IIEP-UNESCO, 2020). Ottawa, 14 May 2020 r. - International education represents a significant economic benefit to Canada, as foreign students contribute 21.6 billion dollars in GDP in Canada and supports almost 170000 working places in 2018 year. Students in this situation can begin their classes, while outside of Canada, and complete $50 \%$ of the program by using distance learning, if they can go to Canada before (Immigration, Refugees and Citizenship Canada, 2020).

The Ministry of Education and Science of Ukraine and postgraduate education institutions paid considerable attention to the possibilities of distance learning in the period COVID-19 (Progress of the MES team..., 2020). At the same time, the number of pedagogical and scientific-pedagogical workers is increasing, who are thus motivated to acquire theoretical and practical skills in mastering cloud services. In Ukraine, at the initiative of the NGO "Consortium of Postgraduate Pedagogical Education", the Ukrainian Open University of Postgraduate Education was established, and the leading role in this 
was played by UEM "University of Educational Management" (Ukrainian Open University of Postgraduate Education, 2021). In order to technically provide distance learning in the system of advanced training for the Ukrainian Open University of Postgraduate Education, an authentic web platform "Learning Management System Adult Learning" - LMS AdL was developed, taking into account the peculiarities of adult learning.

In order to regulate the educational process in quarantine, a number of bylaws were also issued by the Ministry of Education and Science of Ukraine. Thus, the order No 406 "About organizational measures to prevent the spread of coronavirus COVID-19" (2020) provided guidance to heads of institutions and pre-school, general secondary, extra-curricular, professional (vocational) professional pre-higher, higher and postgraduate education for the period of quarantine: "to ensure the implementation of educational programs of educational institutions, in particular by organizing the educational process using distance learning, which does not involve visiting educational institutions by its applicants, and in exceptional cases by consolidating the educational process. educational institutions of other work (organizational and pedagogical, methodical, scientific, etc.), as well as the introduction of flexible (remote) working hours of employees of educational institutions.

Motivation for change, care for children and their education during the quarantine in the spring of 2020 in Ukraine inspired scientists and practitioners to develop and implement platforms for teachers and scientific educational staff. Their details, specifications and course topics are described in Table 2 (COVID-19: How digital learning solutions..., 2020; Kyrychenko et al., 2020).

According to a survey of leaders in $96.9 \%$ of IGME during the quarantine period, students are taught using distance learning technologies. The majority of leaders (75.9\%) noted that the entire teaching staff was involved. However, in almost $20.1 \%$ of schools, distance learning is provided only by teachers who are provided with computer equipment and Internet access. At the same time, $3.12 \%$ of the surveyed IGME leaders stated that their school did not switch to remote work mode for the following reasons: - students and teachers do not have computer equipment and Internet access (30 IGME, $0.76 \%$ of surveyed principals); - most teachers do not have the skills to work remotely (45 IGME, $1.14 \%$ ); - does not allow the speed of Internet communication (32 IGME, 0.81\%) (State Education Quality Service of Ukraine, 2020).

In response to the potential challenges of the second wave of coronavirus, the Ministry of Education and Science of Ukraine has developed recommendations for the organization of blended learning in institutions of higher and professional higher education (2020). Universities and colleges have received advice on how to deploy blended learning, what regulations and technology are needed, how to train staff and plan the learning process. The document contains detailed recommendations for teachers on the creation or adaptation of training courses, planning learning outcomes and effective evaluation of student performance. The recommendations are supplemented by checklists, examples of blended learning models, course planning matrices and other supporting materials that institution leaders and teachers can use in preparation for the new school year.

The organization of blended learning is impossible without the use of an e-learning platform that contains a learning management system LMS. Therefore, to improve distance learning programs, an electronic survey was conducted using the Google Forms web service with limited access to the form. The e-study on the conditions of distance education during life involved from the following regions of Ukraine pedagogical and scientific-pedagogical workers who underwent distance learning: Kyiv, Khmelnytsky region, Kharkiv region, Volyn region, Cherkasy region, Odessa region, Zakarpattia region and Mykolaiv region. The survey was conducted by an associate professor of vocational and higher education at the Central Institute of Postgraduate Education of the State Institution of Higher Education 'University of Educational Management' (UOUPE, 2021). 
Table 2. Popular platforms for teachers and research and educational workers

\begin{tabular}{|c|c|c|}
\hline Platform & Specifications & Course Topics \\
\hline $\begin{array}{l}\text { Higher School of Educational } \\
\text { Management - online platform of } \\
\text { the MCFR Digital Publishing House } \\
\text { for advanced training of } \\
\text { specialists of educational } \\
\text { institutions } \\
\text { https://school.pedrada.com.ua }\end{array}$ & $\begin{array}{l}\text { Training is held in } \\
\text { groups and begins on } \\
\text { the 1st of each } \\
\text { month. The training } \\
\text { program is designed } \\
\text { for two calendar } \\
\text { months }\end{array}$ & $\begin{array}{l}\text { Documents for the Head of Preschool } \\
\text { Institution: State Supervision and } \\
\text { Control } \\
\text { Personnel Documents - } 2020 \text { for the } \\
\text { Head of Educational Institution } \\
\text { Smart Cards in Integrated Learning and } \\
\text { Professional Development } \\
\text { Smart Cards in Preschool Institution } \\
\text { Crisis Management and } \\
\text { Communications in the Institution }\end{array}$ \\
\hline $\begin{array}{l}\text { 'Prometheus' - } \\
\text { Ukrainian public project of mass } \\
\text { open online courses } \\
\text { https://prometheus.org.ua }\end{array}$ & $\begin{array}{l}\text { Designed courses last } \\
\text { several weeks }\end{array}$ & $\begin{array}{l}\text { Science of Teaching: What Should } \\
\text { Every Teacher Know? } \\
\text { Deep Learning } \\
\text { Transformational Pedagogy } \\
\text { Implementation of Innovations in } \\
\text { Schools } \\
\text { Media Literacy for Educators }\end{array}$ \\
\hline $\begin{array}{l}\text { ucation Studio } \\
\text { era.com/ }\end{array}$ & $\begin{array}{lr}\text { Provides } & \text { online } \\
\text { courses, } & \text { textbooks } \\
\text { and special projects }\end{array}$ & $\begin{array}{l}\text { Online Course for Primary School } \\
\text { Teachers } \\
\text { Online Course for Teachers and School } \\
\text { Leaders on Distance Learning } \\
\text { Pro Power Point } \\
\text { \#blend_it: Mastering Blended Learning } \\
\text { and others }\end{array}$ \\
\hline $\begin{array}{l}\text { VUM platform - } \\
\text { Interesting facts not only for } \\
\text { teachers, but also for } \\
\text { schoolchildren and students. } \\
\text { https://vumonline.ua }\end{array}$ & & $\begin{array}{l}\text { School for All: Safe School Environment } \\
\text { How to Conduct EdCamp for Your } \\
\text { Community. }\end{array}$ \\
\hline $\begin{array}{l}\text { Lesson Educational Project } \\
\text { Webinars, conferences, } \\
\text { competitions for educators } \\
\text { https://naurok.com.ua/courses }\end{array}$ & & $\begin{array}{l}\text { Stem Office/Laboratory in Primary } \\
\text { School as a Prequel to Subject Rooms: } \\
\text { Biology, Chemistry and Physics } \\
\text { Media Literacy and Critical Thinking: } \\
\text { from Theory to Practice } \\
\text { Project-Based Teaching Methods } \\
\text { Pedagogy of Trust. }\end{array}$ \\
\hline $\begin{array}{l}\text { Platform 'Be able' - } \\
\text { by Ivan Ivanov, author and } \\
\text { developer of the platform, the } \\
\text { founder of the Center for New } \\
\text { Education., certified Microsoft } \\
\text { expert teacher, organizer of } \\
\text { online competitions for } \\
\text { educators. } \\
\text { https://umity.in.ua }\end{array}$ & $\begin{array}{l}\text { Courses in innovative } \\
\text { pedagogy and ICT }\end{array}$ & $\begin{array}{l}\text { Teach by Storytelling } \\
\text { Orientation in The Methodology of } \\
\text { Training } \\
\text { Develop Interactive Learning Materials } \\
\text { Use Video and Audio in Teaching. }\end{array}$ \\
\hline
\end{tabular}

In Fig. 5. the personal data of pedagogical and scientific-pedagogical workers who took part in interrogation about time possibility for individual training are specified. The survey was conducted in 
the fall of 2020 during the Covid-19 period: $2 \%$ - for life, $2 \%$ - 1-2 hours, $2 \%$ - want to study with a teacher, $11.8 \%$ - depending on the circumstances, $25.5 \%$ - 20 minutes, $47.1 \%$ - 45 minutes (Otamas \& Brin, 2020)

Figure 5. Monitoring of students of the Central Institute of Postgraduate Education about time opportunities for individual learning
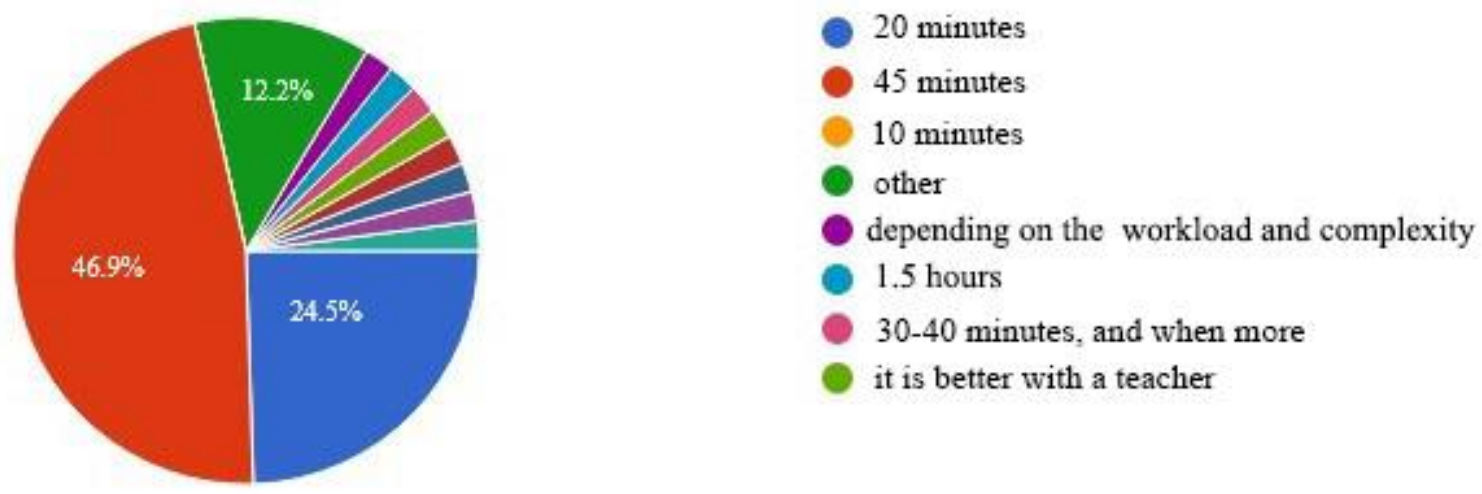

Analyzing the content of the results of an electronic survey conducted using the web service Google Forms, especially in terms of practical difficulties that arise during distance learning of teachers and research and teaching staff, there is a need to solve the problem of educators, which will take into account all the cognitive needs of educators, as well as time opportunities.

\section{Discussion}

This document aimed to examine the perception of teachers and students of the process of online learning and learning during the COVID-19 pandemic. Although the theoretical view underlies the study, the study provides different perspectives on the challenges faced by online learning today. The mixed-use study examined various international organizations that offer a comprehensive list of distance learning solutions, including educational programs, platforms and resources designed to help parents, teachers, schools and school administrators facilitate student learning and provide social assistance and interaction during closure of educational institutions.

A study by L. Mishra, T. Gupta, and A. Shree (2020) highlights the need to make efforts to provide students with free access to online educational resources so that they can make the most of their time during the covid period. Now, for the first time, many teachers in the classroom are trying to understand the intricacies of distance learning and are looking for free online resources for schools that support the perception of our university teachers who also advocated free access to online learning resources.

The transition to online learning through COVID-19 has been a very difficult task for higher education institutions. This is stated in a study by A. Patricia Aguilera-Hermida (2020). The study presents factors, which impact on the use and acceptance of students online learning at the time the order to stay at home due COVID-19. One of the strongest categories of qualitative data showed that after the transition to teaching in the Internet many students have reported, that the teaching in the Internet was an unpleasant experience, and they expressed their negative attitude to learning in the Internet. Not only did they find online learning more difficult, but the lack of support resources (access to a training center, library, interaction with professors, etc.) was an important issue during the transition to online learning.

In a study L. Petrenko (2020), said, that the system of management of educational content (LMS or LCMS) in VET institutions - is software and hardware complex that provides indirect interaction 
between remote participants sustainable training process by using automation of its components and is part of the VET informational and educational the environment of the institution. The most common systems management content teaching in Ukrainian sphere of education - LMS Moodle, eFront, OpenEDX etc. (Petrenko et al., 2020).

\section{Conclusion}

When society is in the recovery phase of COVID-19, it will be a period of critical reflection on the role of education systems and especially vocational education. The global health crisis and the ensuing blockade have led to the respect of those workers who are currently working tirelessly to save the economy. Education plays an important role in developing the competencies and skills needed for tomorrow's society. Real change often takes place in deep crises, and this moment preserves the possibility that we will not return to the status quo when things return to normal. Although this crisis has profoundly devastating consequences, including for education. In this sense, the pandemic is also a call to renew commitment to sustainable development. Providing all young people with the opportunity to succeed in education and develop knowledge, skills, attitudes and values that will enable them to contribute to society is at the heart of the global agenda and the promise of education in our future society.

However, it is a well-established assumption that no pedagogical approach can replace the highest position of formal education through the direct interaction of teachers. But after the COVID-19 crisis, online education became a pedagogical transition from the traditional method to the modern approach of teaching-learning from class to scale, from personal to virtual and from seminars to webinars. Previously, e-learning, distance education and distance learning courses were considered by the people as part of non-formal education, but today it seems to gradually replace the formal education system if the circumstances persist. One of the most popular platforms for communication on the Internet, which could change the direction and direction of the entire education system around the world in the circumstances after COVID-19.

Thus, based on the results of research and analysis of teachers, readiness for the introduction of distance learning technologies in secondary, higher and vocational education institutions, fragments of distance vocational training are used. Some international organizations recognize the promising and appropriate systemic implementation of distance technology in the process of specific subjects. At the same time, problems in the use of distance vocational training related to technical and material situation, which causes difficulties in distance professional activities of the training organization were found, high-quality functional use of electronic platforms; design of distance courses; low level of IT literacy of students and teachers, which complicated the introduction of distance learning technologies; integration of theoretical and practical training in the conditions of distance learning.

The results of research and analysis of survey data, the experience of teachers outlined ways to scientifically solve existing problems, summarized prepared guidelines for improving the implementation of distance learning in vocational education and training. Undoubtedly, the implementation of theoretical and methodological developments in the development of distance education, training, technology requires the consolidation of the efforts of the scientific community with all stakeholders in the process of distance education system development.

\section{Recommendations}

Successful implementation of the Action Plan will include work in close partnership and cooperation with the European Parliament and the Member States, with the active participation of the Committee of the Regions and local authorities. For Member States: Closer cooperation will help to overcome fragmentation policies that could undermine effective digital education policies. There is also a need to strengthen and coordinate work between sectors and policy areas. The Commission will therefore support cooperation and networking at EU level between national structures on digital education. This 
will help facilitate the exchange of best practices across peer learning and support a more consistent and structured approach to digital education policy.

The Commission also organizes field events, in the form of a stakeholder forum, to increase participation - and a sense of ownership - of a wide range of stakeholders. the event will gather Member States, EU institutions and stakeholders in education (including teachers and parent organizations, local authorities, civil society groups and companies - including companies committed to the agenda of the digital education) to share best practices and discuss emerging issues and opportunities.

Digital education can be an important tool for the EU at the international level by exchanging and scaling up best practices and building communities of practice through EU-supported cooperation and projects. A well-functioning education system underpins the European way of life and is essential for the prosperity and stability of the EU, the Member States and our partner country. Digital education initiatives have the potential to strengthen relations between partner countries and the EU, as well as to strengthen relations in various non-EU regions. An open and highly efficient digital education ecosystem in the EU can help attract and nurture excellence around the world as global competition for talent and innovation accelerates. This can help increase the innovation performance of the EU and its member states.

The COVID-19 pandemic has exposed the global digital market share. Strengthening international cooperation on digital education must be an integral part of the EU as a global partner in education. This will be reflected in the EU's international cooperation programs at the global, regional and bilateral levels, including the international dimension of Erasmus +. In particular, the EU, in line with Team Europe's approach, will contribute to the global development of cooperation while addressing its strategic objectives in priority regions, especially the Western Balkans, Africa and the Eastern Partnership and the Southern Mediterranean, based on Digital4Development Hub.

\section{Acknowledgments}

The article was prepared in the framework of the study "Transformation of professional development of pedagogical and academic workers in the conditions of an open university of postgraduate education" RK $0120 \mathrm{U} 104637$.

\section{References}

1. Aguilera-Hermida, A. (2020). College students' use and acceptance of emergency online learning due to COVID-19. International Journal of Educational Research Open, 1. Retrieved from https://www.sciencedirect.com/science/article/pii/S266637402030011X

2. Al-Samarrai, S., Gangwar, M., \& Gala, P. (2020). The Impact of the COVID-19 Pandemic on Education Financing. Retrieved from

https://openknowledge.worldbank.org/bitstream/handle/10986/33739/The-Impact-of-theCOVID-19-Pandemic-on-Education-Financing. pdf?sequence=1\&isAllowed=y

3. Anishchenko, V.O., Margasova, V.G., \& Tkalenko, N.V. (2010). Peculiarities of company's strategic development aiming at ITS cost increase. Actual Problems of Economics, 2, 67-75.

4. Australian Government. (2020). Higher education relief package. Retrieved from https://ministers.dese.gov.au/tehan/higher-education-relief-package

5. Borysenko, I.V., Bykonia, O.P., Rembach, O.O., Shumna, L.P., Oliinyk, O.I., \& Anishchenko, V.O. (2020). Experience of ICT implementation in primary curriculum in Ukraine and the United Kingdom of Great Britain and Northern Ireland. Information Technologies and Learning Tools, 75(1), 42-55.

6. COL. (2020). Guidelines on Distance Education during COVID-19. Burnaby: COL. Retrieved from https://iite.unesco.org/wp-content/uploads/2020/05/Guidelines-on-DE_COVID-19.pdf 
7. COVID-19: How digital learning solutions are taking shape. (2020). Retrieved from https://news.itu.int/covid-19-how-digital-learning-solutions-are-taking-shape/

8. COVID-19: Why investing in youth will future-proof the economy. (2020). Retrieved from https://www.weforum.org/agenda/2020/07/covid-19-why-investing-in-youth-will-future-proofthe-economy

9. Distance learning solutions. (2020). More on UNESCO's COVID-19 Education Response. Retrieved from https://en.unesco.org/covid19/educationresponse/solutions

10. Education responses to COVID-19: embracing digital learning and online collaboration. (2020). Retrieved from https://www.oecd.org/coronavirus/policy-responses/education-responses-tocovid-19-embracing-digital-learning-and-online-collaboration-d75eb0e8/

11. IIEP-UNESCO. (2020). What price will education pay for COVID-19. Retrieved from http://www.iiep.unesco.org/en/what-price-will-education-pay-covid-19-13366

12. Immigration, Refugees and Citizenship Canada. (2020). Flexibility in post-graduation work permit rules to help international students and Canadian post-secondary institutions. Retrieved from https://www.canada.ca/en/immigration-refugees-citizenship/news/notices/pgwpp-rulescovid19.html

13. International Association of Universities (2020). Regional/National Perspectives on the Impact of COVID-19 on Higher Education. Retrieved from https://www.iau-aiu.net/IMG/pdf/iau_covid19_regional_perspectives_on_the_impact_of_covid-19_on_he_july_2020_.pdf

14. International partnership of distance and online learning for COVID-19. (2020). Retrieved from https://iite.unesco.org/news/international-partnership-of-distance-and-online-learning-for-covid19/

15. Join paper: IAU and ESN COVID-19 impact on Higher Education: Institutional and Students' Perspectives. (2020). Retrieved from https://www.iau-aiu.net/IMG/pdf/joint_paper_iau_and_esn__institutional_and_students_perspectives_of_covid-19_impact_on_higher_education.pdf

16. Keeping the doors of learning open COVID-19. (2020). Retrieved from https://www.col.org/resources/keeping-doors-learning-open-covid-19

17. Kozlovskyi, S., Butyrskyi, A., Poliakov, B., Bobkova, A., Lavrov, R., \& Ivanyuta, N. (2019). Management and comprehensive assessment of the probability of bankruptcy of Ukrainian enterprises based on the methods of fuzzy sets theory. Problems and Perspectives in Management, 17(3), 370-381. doi:10.21511/ppm.17(3).2019.30

18. Kyrychenko, M., Otamas, I., \& Bryn, L. (2020). Digital literacy in the open education of Ukraine and the EU during Covid-19. In: The Ukrainian Yearly book of European Integration Studies (pp. 155170). Kyiv: Aprei.

19. Mishra, L., Gupta, T., \& Shree, A. (2020). Online teaching-learning in higher education during lockdown period of COVID-19 pandemic. International Journal of Educational Research Open, 1. Retrieved from https://www.sciencedirect.com/science/article/pii/S2666374020300121

20. National learning platforms and tools. (2021). More on UNESCO's COVID-19 Education Response. Retrieved from https://en.unesco.org/covid19/educationresponse/nationalresponses

21. OECD. (2020a). Education at a Glance 2020: OECD Indicators. Paris: OECD Publishing.

22. OECD. (2020b). VET in a time of crisis: building foundations for resilient vocational education and training systems. Retrieved from https://read.oecd-ilibrary.org/view/?ref=132_132718fdwmrqsgmy\&title=VET-in-a-time-ofcrisis-Building-foundations-for-resilient-vocational-educationand-training-systems

23. Order No 406 of the Ministry of Education and Science of Ukraine. (2020). About organizational measures to prevent the spread of coronavirus COVID-19. Retrieved from 
https://mon.gov.ua/ua/npa/pro-organizacijni-zahodi-dlya-zapobigannya-poshirennyukoronavirusu-s-ovid-19

24. Otamas, I., \& Brin L. (2020). Development of open education (2000-2020): a retrospective review of Ukrainian, European and international experience. In Scientific-Practical Conference with International Participation Professional Development of Specialists in the Context of Digitalization of Society (Kyiv, 12-13 November) (pp. 74-80). Zhytomyr: ZhSU named after I. Franko.

25. Petrenko, L., Kravets, S., Bazeliuk, O., Maiboroda, L., \& Muzyka, I. (2020). Analysis of the current state of distance learning in the vocational education and training institution. E3S Web of Conferences, 166, 1-7. DOI: 10.1051/e3sconf/202016610010.

26. Progress of the MES team to strengthen the education and science system of Ukraine: digitalization and online services. (2020). Retrieved from https://mon.gov.ua/ua/news/postup-komandi-monna-zmicnennya-sistemi-osviti-i-nauki-ukrayini-didzhitalizaciya-ta-onlajn-poslugi

27. Recommendations for the organization of blended learning in institutions of higher and professional higher education. (2020). Retrieved from https://mon.gov.ua/ua/osvita/vishaosvita/rekomendacij-shodo-vprovadzhennya-zmishanogo-navchannya-u-zakladah-fahovoyiperedvishoyi-ta-vishoyi-osviti

28. State Education Quality Service of Ukraine. (2020). Analytical information on the organization of distance learning in general secondary education in quarantine. Retrieved from http:// www.sqe.gov.ua/index.php/uk-ua/hovyny/1217-rezultaty-opytuvannia-shchododystantsiinohonavchannia-v-zakladakh-zahalnoi-serednoi-osvity

29. The impact of COVID-19 on education insights from education at a glance 2020. (2020). Retrieved from http://www.oecd.org/education/the-impact-of-covid-19-on-education-insights-educationat-a-glance-2020.pdf

30. Ukrainian Open University of Postgraduate Education (UOUPE). (2021). Retrieved from http://uvu.org.ua/

31. Yaroshenko, O. M., Vapnyarchuk, N. M., Lozovoi, S. V., Yakovleva, G. O., \& Yakovlyev, O. A. (2018). General-compulsory medical insurance: World experience. Journal of Advanced Research in Law and Economics, 9(5), 1829-1838. 